\title{
MET Tyrosine Kinase Inhibitor EMD 1204831
}

National Cancer Institute

\section{Source}

National Cancer Institute. MET Tyrosine Kinase Inhibitor EMD 1204831. NCI Thesaurus.

Code C91097.

An inhibitor of the receptor tyrosine kinase Met (hepatocyte growth factor receptor) with potential antineoplastic activity. MET inhibitor EMD 1204831 selectively binds to Met tyrosine kinase, thereby disrupting MET mediated signal transduction pathways. This may induce cell death in tumor cells overexpressing this kinase. MET is overexpressed or mutated in many tumor cell types, and plays key roles in tumor cell proliferation, survival, invasion, and metastasis, and tumor angiogenesis. 